\title{
INOVASI OLAHAN DURIAN
}

\author{
Waryono $^{1^{*}}$ \\ ${ }^{1}$ Jurusan Pariwisata, Fakultas Pariwisata dan Perhotelan, Universitas Negeri Padang \\ *Corresponding author, e-mail: waryono19812012@gmail.com
}

\begin{abstract}
Abstrak- Kenagarian Barung Barung Belantai Selatan Kecamatan Koto XI Tarusan merupakan nagari pemekaran tahun 2009 dari kenagarian induk Barung Barung Belantai. Daerah ini memiliki potensi pertanian yang sangat besar seperti tanaman gambir, pala, cengkeh, karet terutama tanaman durian yang melimpah. Melimpahnya potensi ini bisa dilihat disepanjang jalan Padang-Painan, banyak pedagang durian berjejeran, dan ini menjadi daya tarik tersendiri bagi orang yang datang berkunjung ke Pesisir Selatan. Pengunjung pasti singgah untuk sekedar mencicipi rasa buah durian yang terkenal enak dan legit. Setiap panen durian buah melimpah sehingga harga jual durian terkadang menjadi murah. Belum lagi biaya transportasi membawa panen durian dari ladang/perkebunan warga membutuhkan biaya yang besar. Akibatnya warga terkadang membiarkan saja panen durian terbuang sia-sia. Universitas Negeri Padang melaksanakan pelatihan bagi ibu-ibu rumah tangga membuat aneka olahan durian menjadi cake durian dan wingko durian. Wali nagari setempat mengharapkan warga dapat mengolah durian menjadi makanan khas dan oleh-oleh dari daerah ini sehingga mampu meningkatkan ekonomi keluarga serta mendukung pengembangan pariwisata Pesisir Selatan.
\end{abstract}

Kata Kunci: cake; durian; pariwisata; wingko.

\begin{abstract}
Kenagarian Barung Barung Belantai Selatan District of Koto XI Tarusan an expansion in 2009 villages of the parent Kenagarian Barung Barung Belantai. This area has a huge agricultural potential such as gambier plant, nutmeg, clove, rubber especially durian abundant. The abundance of this potential can be seen along the road Padang to Painan, many traders durian, and this is the main attraction for people who come to visit the Pesisir Selatan. Visitors would stop by for a taste of durian famous delicious and sticky. Each harvest durian fruit durian abundance so that the selling price is sometimes cheaper. Not to mention the cost of transport to bring durian harvest from the farm/plantation residents require huge costs. As a result, residents sometimes let alone durian harvest wasted. State University of Padang conducted training for mothers of households made into various processed durian cake durian and wingko durian. Wali local village residents can expect to process durian become typical food and souvenirs from this area so as to increase family economy and to support the development of the tourism of Pesisir Selatan.
\end{abstract}

Keywords: cake; durian; tourism; wingko.

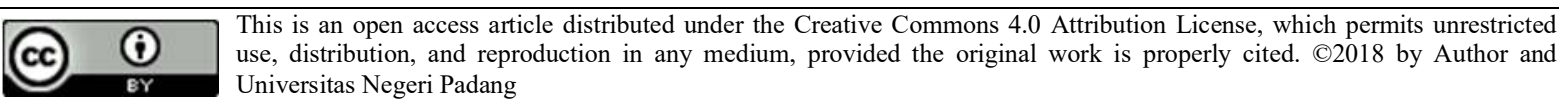

\section{Pendahuluan}

Kenagarian Barung-Barung Belantai Selatan Kecamatan Koto XI Tarusan merupakan nagari pemekaran tahun 2009 dari kenagarian induk Barung Barung Belantai. Daerah ini memiliki potensi pertanian yang sangat besar seperti tanaman gambir, pala, cengkeh, karet terutama tanaman durian yang melimpah. Setiap warga dikenagarian ini pasti memiliki pohon durian.
Sebab dari luas wilayah yang ada sekitar 15,52 $\mathrm{km}$ lebih dari $50 \%$ luas wilayahnya ditanami pohon durian. Dahulunya daerah ini sudah dikenal oleh masyarakat luas sebagai daerah penghasil durian. Melimpahnya potensi ini bisa dilihat disepanjang jalan raya Padang - Painan, banyak pedagang durian berjejeran, dan ini menjadi daya tarik tersendiri bagi orang yang datang berkunjung ke Pesisir Selatan. Pengunjung pasti singgah 
untuk sekedar mencicipi rasa buah durian yang terkenal enak dan legit. Setiap panen durian buah melimpah sehingga harga jual durian terkadang menjadi murah. Belum lagi biaya transportasi membawa panen durian dari ladang/perkebunan warga membutuhkan biaya yang besar. Akibatnya warga terkadang membiarkan saja panen durian terbuang sia-sia ${ }^{[6]}$.

Universitas Negeri Padang melalui Lembaga Pengabdian Kepada Masyarakat bekerjasama dengan Fakultas Pariwisata dan Perhotelan tertantang untuk mengatasi permasalahan ini. Salah satu bentuk kegiatan yang dilakukan adalah penyuluhan dan pelatihan keterampilan membuat aneka olahan durian sebagai makanan khas dan oleh-oleh dari daerah ini.

Memanfaatkan potensi panen durian yang melimpah dengan mengolah durian menjadi makanan yang bernilai jual tinggi, sehingga masyarakat dapat memperoleh keuntungan setiap panen durian. Disamping ikut membantu masyarakat untuk meningkatkan kesejahteraan dan perekonomian keluarga.

Secara tradisional, daging buah durian yang berlebih-lebihan ini biasa diawetkan dengan memasaknya bersama gula menjadi dodol durian (biasa disebut lempok), atau memfermentasikannya menjadi tempoyak [9]. Selanjutnya, tempoyak yang rasanya masam ini biasa menjadi bahan masakan seperti sambal tempoyak, atau untuk campuran memasak ikan. Durian pun kerap diolah menjadi campuran bahan kue-kue tradisional, seperti gelamai atau jenang. Terkadang, durian dicampurkan dalam hidangan nasi pulut (ketan) bersama dengan santan [4].

Dalam dunia masa kini, durian (atau aromanya) biasa dicampurkan dalam permen, es krim, susu, dan berbagai jenis minuman penyegar lainnya [8]. Bijinya bisa dimakan sebagai camilan setelah direbus atau dibakar, atau dicampurkan dalam kolak durian. Biji durian yang mentah beracun dan tak dapat dimakan karena mengandung asam lemak siklopropena (cyclopropene). Biji durian mengandung sekitar $27 \%$ amilosa [7].

Durian adalah nama tumbuhan tropis yang berasal dari wilayah Asia Tenggara, sekaligus nama buahnya yang bisa dimakan. Nama ini diambil dari ciri khas kulit buahnya yang keras dan berlekuk-lekuk tajam sehingga menyerupai duri. Sebutan populernya adalah "raja dari segala buah" (King of Fruit). Durian merupakan buah yang kontroversial, meskipun banyak orang yang menyukainya, namun sebagian yang lain malah muak dengan aromanya. Sesungguhnya, tumbuhan dengan nama durian bukanlah spesies tunggal tetapi sekelompok tumbuhan dari marga Durio. Namun, yang dimaksud dengan durian (tanpa imbuhan apa-apa) biasanya adalah Durio zibethinus. Jenis-jenis durian lain yang dapat dimakan dan kadangkala ditemukan di pasar tempatan di Asia Tenggara di antaranya adalah lai (D. kutejensis), kerantungan (D. oxleyanus), durian kura-kura atau kekura (D. graveolens), serta lahung (D. dulcis). Beberapa ras lokal belum diseleksi, sehingga masih bervariasi dan keunggulannya belum terjamin. Biasanya dinamakan sesuai lokasi geografi. Beberapa di antaranya adalah: Durian Parung, Durian Lampung, Durian Jepara, Durian Palembang, Durian Padang [10].

Buah durian bertipe kapsul berbentuk bulat, bulat telur hingga lonjong, dengan panjang hingga $25 \mathrm{~cm}$ dan diameter hingga $20 \mathrm{~cm}$. Kulit buahnya tebal, permukaannya bersudut tajam ("berduri", karena itu disebut "durian", walaupun ini bukan duri dalam pengertian botani), berwarna hijau kekuning-kuningan, kecoklatan, hingga keabuabuan.

Buah berkembang setelah pembuahan dan memerlukan 4-6 bulan untuk pemasakan. Pada masa pemasakan terjadi persaingan antarbuah pada satu kelompok, sehingga hanya satu atau beberapa buah yang akan mencapai kemasakan, dan sisanya gugur. Buah akan jatuh sendiri apabila masak. Pada umumnya berat buah durian dapat mencapai 1,5 hingga 5 kilogram, sehingga kebun durian menjadi kawasan yang berbahaya pada masa musim durian. Apabila jatuh di atas kepala seseorang, buah durian dapat menyebabkan cedera berat atau bahkan kematian [11].

Setiap buah memiliki lima ruang (awam menyebutnya "kamar"), yang menunjukkan banyaknya daun buah yang dimiliki. Masingmasing ruangan terisi oleh beberapa biji, biasanya tiga butir atau lebih, lonjong hingga $4 \mathrm{~cm}$ panjangnya, dan berwarna merah muda kecoklatan mengkilap. Biji terbungkus oleh arilus (salut biji, yang biasa disebut sebagai "daging buah" durian) berwarna putih hingga kuning terang dengan ketebalan yang bervariasi, namun pada kultivar unggul ketebalan arilus ini dapat mencapai $3 \mathrm{~cm}$. Biji dengan salut biji dalam perdagangan disebut ponggè. Pemuliaan durian diarahkan untuk menghasilkan biji yang kecil dengan salut biji yang tebal, karena salut biji inilah bagian yang dimakan. Beberapa varietas unggul menghasilkan buah dengan biji yang tidak berkembang namun dengan salut biji tebal (disebut "sukun") [1]. 


\section{METODOLOGI}

Kegiatan penyuluhan dan pelatihan keterampilan membuat aneka olahan durian ini terdiri dari 2 (dua) kegiatan yaitu penyuluhan dan pelatihan. Kegiatan penyuluhan diberikan berkaitan dengan pemberian teori tentang durian dan aneka olahannya. Pelaksana menerapkan metode ceramah dan tanya jawab dalam kegiatan penyuluhan kepada masyarakat. Sedangkan kegiatan pelatihan pelaksana menerapkan metode demonstrasi dan latihan langsung kepada masyarakat tentang cara membuat aneka olahan durian. Pelaksana telah menyiapkan peralatan pengolahan dan bahan sesuai resep, kecuali durian. Masyarakat diminta untuk menyiapkan durian sebanyak resep yang akan diolah.

\section{HASIL DAN PEMBAHASAN}

Kegiatan penyuluhan dan pelatihan membuat aneka olahan durian ini dilaksanakan di sebuah sekolah PAUD di Barung Barung Belantai Tengah yang dihadiri oleh 20 orang wanita dan umumnya ibu-ibu rumah tangga dan remaja putri. Pelaksanaan kegiatan dimulai dengan melakukan penyuluhan tentang buah durian dan pengetahuan aneka olahan durian. Durian terutama dipelihara orang untuk buahnya, yang umumnya dimakan (arilus atau salut bijinya) dalam keadaan segar. Salut biji ini umumnya manis dan sangat bergizi karena mengandung banyak karbohidrat, lemak, protein, dan mineral. Nilai nutrisi per 100 gram buah durian sebagai berikut: energi $615 \mathrm{~kJ}$ (147 kcal), karbohidrat 27.09 gram, serat pangan 3.8 gram, lemak 5.33 gram, protein 1.47 gram, air 65 gram, vitamin C $19.7 \mathrm{mg}$ (33\%), dan kalium 436 $\mathrm{mg}(9 \%)$ [11]. (Hanya bagian yang dapat dimakan, mentah atau beku. Brangkasan: 68\% (Shell and seeds). Sumber: USDA Nutrient database [12] Persentase merujuk kepada rekomendasi Amerika Serikat untuk dewasa).

Berbagai hasil olahan durian antara lain: dodol durian, es campur, es krim durian, kolak ketan durian, pancake durian, wajik durian, cake durian, onde-onde durian, dan wingko durian [4]. Beberapa hal penting yang juga disampaikan tentang faktor-faktor penentu keberhasilan pengolahan makanan meliputi: pemilihan bahan yang bermutu baik agar menghasilkan produk makanan yang berkualitas baik, penggunaan peralatan pengolahan yang bersih dan tepat, pemeliharaan hygiene dan sanitasi selama proses pengolahan makanan, serta teknik dan metode pengolahan yang benar sesuai dengan petunjuk resep yang telah diberikan [5].

Pelaksanaan kegiatan pelatihan peserta sangat antusias mengikuti demonstrasi yang dilakukan oleh pelaksana. Adapun resep yang dicobakan adalah pembuatan wingko durian [3] dan cake durian [2]. Setelah peserta melihat peragaan langkah demi langkah pembuatan kue tersebut, pelaksana langsung membagi peserta ke dalam 2 (dua) kelompok, dimana masing-masing kelompok membuat wingko durian dan cake durian.

\section{WINGKO DURIAN}

\section{Bahan A:}

400 gr tepung ketan

100 gr tepung kanji

1000 gr kelapa parut, kukus selama 5 menit

600 gr gula pasir

2 sdt garam halus

\section{Bahan B:}

400 cc santan kental

3 lembar daun pandan

2 butir telur

$200 \mathrm{gr}$ daging buah durian, diblender halus

\section{Cara Membuat:}

1) Campurkan semua bahan A, aduk rata. Sisihkan.

2) Campurkan semua bahan $B$, lalu masak di atas kompor dengan api sedang sambil diaduk rata hingga matang.

3) Masukkan campuran bahan A ke dalam adonan $\mathrm{B}$, aduk rata dan kalis.

4) Cetak bulat-bulat, lalu panggang secara bolakbalik di atas pandadar Teflon.

5) Angkat dan sajikan.

Bahan:

\section{CAKE DURIAN}

200 gr tepung terigu protein sedang

$1 \frac{1}{2}$ sdt Baking Powder

1 sdt soda kue

$1 / 2$ sdt garam halus

100 gr gula pasir halus

200 gr margarine

4 butir telur

200 gr daging buah durian 


\section{Cara Membuat:}

1) Panaskan Oven hingga suhu $170^{\circ} \mathrm{C}$.

2) Olesi cetakan persegi empat ukuran $20 \times 20 \mathrm{x}$ $7 \mathrm{~cm}$ dengan sedikit minyak. Sisihkan.

3) Ayak tepung terigu bersama Baking Powder, soda kue, dan garam. Sisihkan.

4) Kocok gula dan margarine sampai putih dan lembut.

5) Masukkan telur satu persatu sambil di kocok terus sampai adonan kental.

6) Masukkan durian, kocok rata. Tambahkan campuran terigu, aduk rata.

7) Tuang ke dalam cetakan, ratakan.

8) Panggang dalam oven selama 35-40 menit hingga matang.

9) Angkat, keluarkan dari cetakan. Dinginkan dan sajikan.

Peralatan yang dipergunakan dalam pengolahan wingko durian dan cake durian antara lain: waskom stainless steel, panci bertangkai, sendok kayu, pandadar teflon, mixer, ayakan, gelas ukur, timbangan, sendok takar, loyang persegi empat ukuran $20 \times 20 \times 7 \mathrm{~cm}$, spatula, piring bulat ceper, kukusan, oven, dan kompor.

Peserta kegiatan penyuluhan dan pelatihan keterampilan membuat aneka olahan durian sangat puas terhadap pelaksanaan kegiatan ini. Selama ini masyarakat mengolah durian secara sederhana saja dan tidak terpikirkan untuk meningkatkan nilai jualnya.

Pelatihan yang diberikan telah mendorong masyarakat untuk berwirausaha dengan menggunakan bahan-bahan dan peralatan sederhana serta metode pengolahan yang singkat dapat menghasilkan wingko durian dan cake durian yang bernilai jual tinggi. Apalagi hasil produksi wingko dan cake durian bisa langsung dinikmati bersama. Peserta mengharapkan kegiatan ini tetap dilanjutkan pada waktu yang akan datang.

Rangkaian kegiatan penyuluhan dan pelatihan keterampilan ini juga terungkap tentang cara memilih buah durian yang baik. Durian adalah buah musiman yang dulunya dipanen sekali setahun. Sekarang panen durian dapat dilakukan hingga dua kali setahun. Hal ini meningkatkan persaingan di antara para penjual eceran. Memilih buah yang tepat amat penting apabila penjual menjual buah sebagaimana adanya, tanpa boleh dibuka. Sekarang penjual umumnya mau membuka buah untuk membuktikan isinya. Dengan cara ini, keahlian dalam memilih pun menjadi kurang penting. Orang dapat memilih durian dengan mudah di kebun. Buah dari pohon yang sama umumnya mempunyai ciri-ciri yang serupa. Lazimnya buah di kebun dibiarkan masak dan jatuh dari pohonnya ("duren jatuhan").

Pemilihan buah di luar kebun lebih rumit. Berikut ini adalah sebagian dari pedoman seleksi yang dapat digunakan [13]:

a. Kesegaran buah dapat ditentukan dari tangkainya. Apabila buah telah jatuh dari pohon, tangkainya akan mulai mengering. Penjual yang tidak jujur akan mencoba untuk membalut atau mengecat tangkai untuk menghalangi pembeli mengenali kesegarannya. Penjual yang kurang pintar mungkin malah akan membuang tangkai durian.

b. Kebanyakan peminat menggemari buah durian yang kering dan matang. Sebuah cara mudah untuk mengetahui apakah isi durian itu kering tanpa membuka buah adalah dengan menggoncangkan buah dan merasakan getaran kecil. Isi durian yang lembap melekat pada kulit buah. Isi durian yang kering cenderung untuk berpisah dari dinding buah. Orang mestilah berhati-hati agar tidak tergores oleh duri buah durian ketika melakukan ini.

c. Durian mungkin diserang oleh ulat perusak yang bertelur di dalam buah yang berkembang menjadi larva. Ketika membeli buah durian pembeli harus menghindari buah yang berlubang pada kulitnya karena sering kali ini merupakan tanda adanya "ulat" di dalam buah.

\section{SIMPULAN}

Kegiatan penyuluhan dan pelatihan keterampilan membuat aneka olahan durian bagi ibu-ibu rumah tangga dan remaja putri di kenagarian Barung-Barung Belantai Selatan merupakan wujud tri dharma perguruan tinggi yaitu pengabdian kepada masyarakat. Lokasi yang dipilih adalah daerah terkenal dengan durian yang enak dan legit di Sumatera Barat. Pelatihan keterampilan yang diberikan adalah membuat cake durian dan wingko durian. Kegiatan ini mendorong masyarakat untuk berwirausaha dengan menggunakan bahan-bahan dan peralatan sederhana serta metode pengolahan yang singkat, namun menghasilkan produk dengan nilai jual tinggi. Wali nagari setempat mengharapkan warga dapat mengolah durian menjadi makanan khas dan oleh-oleh dari daerah ini sehingga mampu meningkatkan ekonomi keluarga serta mendukung pengembangan pariwisata Pesisir Selatan. 


\section{DAfTAR PUStaka}

[1] Ide Masak. 2012. All About Durian. Jakarta: PT. Gramedia Pustaka Utama.

[2] Kartini. Jamuan Lebaran 2006. Bolu Durian. Hal 72.

[3] Lilly T Erwin. 2003. Seri Makanan Favorit: Variasi Kue Wingko. Jakarta: PT. Gramedia Pustaka Utama.

[4] Nindya Widoyo. 2010. 40 Sajian Lezat Hasil Olah Durian. Jakarta: PT. Gramedia Pustaka Utama.

[5] Yeni Ismayani. 2012. 101 Tips Jitu Antigagal: Sukses Membuat Cake. Jakarta: PT. Gramedia Pustaka Utama.

[6] http://berita.pesisirselatankab.go.id /berita/detail/buah-durian-melimpah-dikenagarian-barung-barung-balantaiselatan Diakses tanggal 28 Juli 2018 12.27 WIB

[7] http:/gizigizian.blogspot.com/ 2014/06/manfaat-durian-danbijinya.html Diakses tanggal 28 Juli 2018 12.46 WIB

[8] https://blog.tokopedia.com/2015/03/kamupecinta-durian-ini-dia-10-makanan-olahandari-durian-yang-wajib-dicoba/ Diakses tanggal 31 Maret 2016 11.35 WIB

[9] http://www.satujam.com/ini-dia- anekaolahan-durian-yang-bikin-kamu-ngiler/

Diakses tanggal 31 Maret 201611.37 WIB

[10] http://id.wikipedia.org/wiki/Durian Diakses tanggal 31 Maret 201611.00 WIB

[11] http://uternak.blogspot.com/2013/03/ budidaya-durian_10.html Diakses tanggal 28 Juli $201812 . \overline{49}$ WIB

[12] https://www.tipscaramanfaat.com/ kandungan-gizi-dan-manfaat-buah-durian469.html Diakses tanggal 28 Juli 2018 12.52 WIB

[13] https://www.kompasiana.com/ridwan. sami/ 500f601a3331118705126b3/caramemilih-durianDiakses tanggal $28 \mathrm{Juli}$ 201812.59 WIB

\section{BiodataPenulis}

Waryono, lahir di Palembang, 30 Maret 1981. Sarjana Pendidikan Kesejahteraan Keluarga konsentrasi Tata Boga dari Universitas Negeri Padang, lulus tahun 2005. Melanjutkan program Magister di Sekolah Tinggi Pariwisata Bandung pada bidang keahlian Manajemen Perhotelan, lulus tahun 2012. Sejak tahun 2006 sebagai staf pengajar pada jurusan Kesejahteraan Keluarga program studi Tata Boga FT UNP. Saat ini tercatat sebagai staf pengajar pada Jurusan Pariwisata Fakultas Pariwisata dan Perhotelan program studi Manajemen Perhotelan sejak tahun 2009 - sekarang. 
